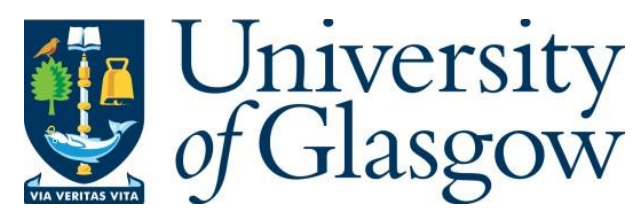

Given, M. (2017) Global peasant, local elite: mobility and interaction in Ottoman Cyprus. Journal of Islamic Archaeology, 4(1), pp. 1-21.

There may be differences between this version and the published version. You are advised to consult the publisher's version if you wish to cite from it.

http://eprints.gla.ac.uk/139040/

Deposited on: 30 May 2017

Enlighten - Research publications by members of the University of Glasgow http://eprints.gla.ac.uk 


\title{
Global peasant, local elite: mobility and interaction in Ottoman Cyprus
}

Michael Given, University of Glasgow, Scotland

E-mail: Michael.Given@glasgow.ac.uk

\begin{abstract}
This article challenges the polarisation, still common in accounts of Ottoman Cyprus and elsewhere, of an oppressed, isolated peasantry and the power and connectedness of the elite. By integrating archaeological, historical and ethnographic evidence, it examines the specific mechanisms of production, exchange and movement across the Cypriot landscape. The patterns of activities of the peasantry show not just a deep rooting in their community landscape but also a striking mobility and agency: they had a significant ability to negotiate, participate and protest in the distributed power system of the Ottoman empire, and show intense movement and widespread connections across the island and beyond. The elite participated in a series of regional and Mediterranean-wide networks, and had many opportunities to increase their wealth, political power and social position. But they were also deeply embedded in agricultural production and in the land. The landscape of Ottoman Cyprus, then, is characterised by intense interaction at all levels, by a highly connected peasantry as much as by a localised elite.
\end{abstract}

\section{Keywords}

Cyprus, Ottoman, landscape, peasant, interaction, mobility

\section{Local peasant, global elite}

There are two conflicting visions of the social organisation of the landscape of Ottoman Cyprus, driven mainly by disciplinary divides. On one side is a close-knit village community of peasant farmers, based on subsistence agriculture and linked by intricate but very local connections. On the other is the large-scale economics of cash cropping, international trade and estates owned and exploited by local and foreign notables, usually at the expense of the peasants.

Ethnographers and folklorists, as well as to some degree archaeologists, have produced a wealth of ethnographic detail about peasant communities, with a nuanced and detailed understanding of the seasonal cycles, vernacular architecture, folk art and material culture that structured their communities (e.g. Ionas 1988; 1994; Rizopoulou-Egoumenidou 1998). Clearly there was, to a degree, subsistence agriculture, particularly in the hill country (Ionas 1994, 433), and taxation records show crops such as legumes, tree fruit and garden produce in amounts more suitable for immediate consumption than for local or more distant trade (Given and Hadjianastasis 2010, 53-54; Hadjikyriacou 2011, 38; Jennings 1986). But it is all too easy to slip into a romanticised image of the totally self-sufficient peasant, isolated from the world beyond the confines of their own village (e.g. Christodoulou 1959, 96-101; Rizopoulou-Egoumenidou 1996, 197). This ignores peasants' ability and need to sell on the market, their relations with moneylenders, merchants and tax farmers, and also their mobility, a key characteristic of peasant society (Figure 1; Smith 2014). Ultimately, this is a picture of a peasantry stripped of any context. 


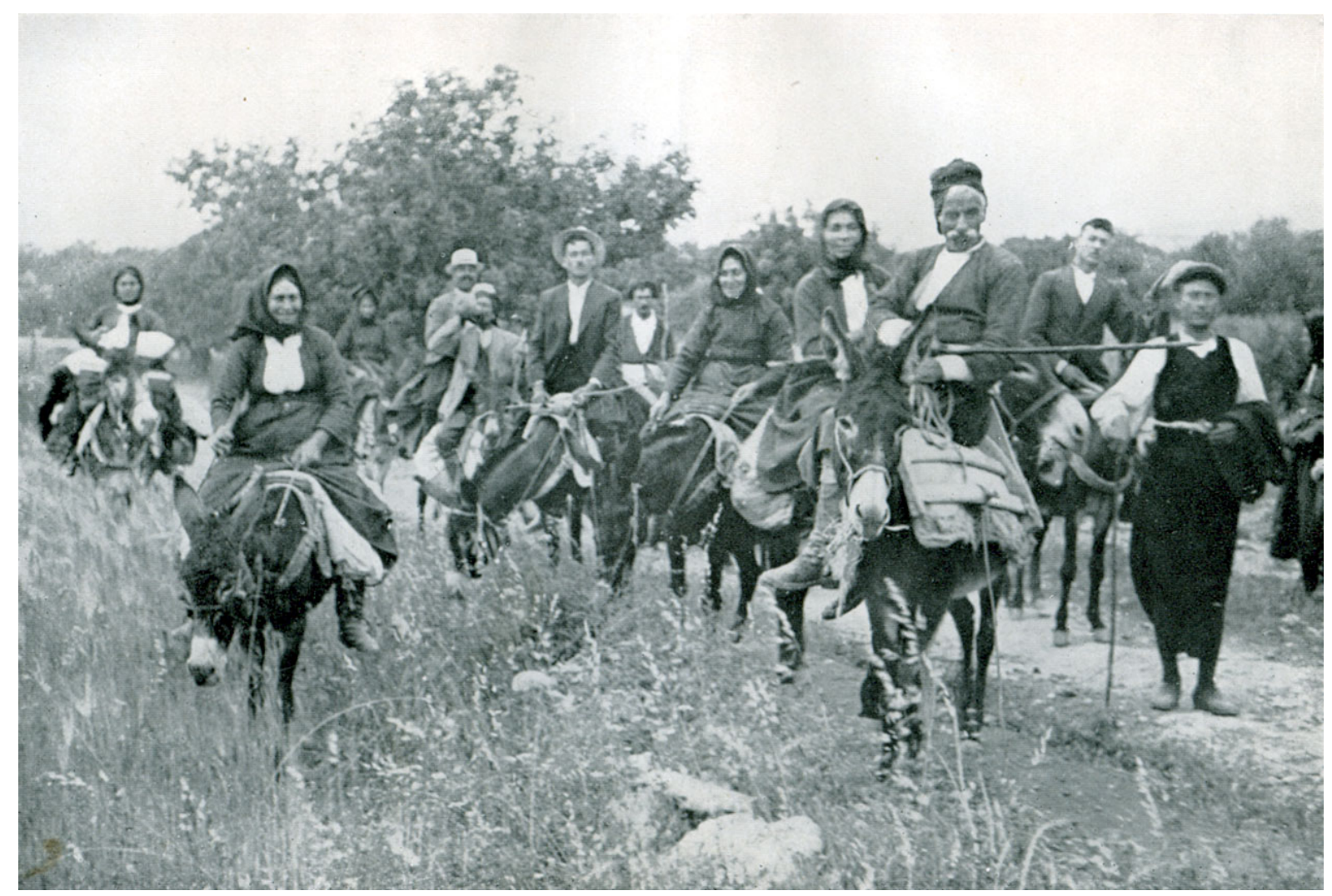

Figure 1. Villagers arriving at the fair of St George at Cape Drepano near Peyia in the 1930s (Chapman 1937, 145; see also 179-181)

The particular concerns of the historical documents, whether travellers' accounts, Ottoman administrative documents or the reports of the foreign consuls, lend themselves to an analysis of the role of the elite, particularly their economic behaviour and the operation of trade, exchange and taxation. It is an easy assumption that their power and wealth gives them social and historical agency, that unlike the peasants whose labour they exploit they are the drivers of history. Even though there has been some important work on the agency and resistance of peasants, all too often their role is reduced to being the pawns of the elite (Faroqhi 2009b, 91). This is exacerbated by their petitions protesting the 'oppression and transgression' of tax collectors and local officials. While the elite of Ottoman Cyprus most certainly sought to increase their profits, often at the expense of the peasantry, these petitions effected much more than merely expressing peasant impotence against elite power and agency (Hadjikyriacou 2014).

Both these visions of Ottoman Cyprus are bound up with stereotypes of power and powerlessness, exacerbated by nationalist historiographies and institutionalised as a 'narrative of suffering', setting an oppressed peasantry against the oppressive regime and conspicuous consumption of the elite (Hadjianastasis 2014; Michael 2009, 14-15). There is a broader tension here. Microhistorical case studies, including archaeological surveys, can engage with specific situations and local conditions, but often fail to contextualise them at an empire- or Mediterranean-wide scale. 'Big picture' analyses, particularly when they set centre against periphery, tend to over-emphasise the uniformity of social processes across the Empire (e.g. Baram and Carroll 2000; see Hadjikyriacou 2015a). 
Empires in general, and the Ottoman Empire in particular, operate by means of negotiation and balance, at a local as much as an empire-wide level; power is distributed, intricate and varied (Aymes 2014, 178-180; Hadjikyriacou 2014; 2015a). Peasants are participants in the imperial project just as much as Sultans, governors and tax collectors. They can choose to cultivate or not, to stay or to flee; they can negotiate deals with the purchasers of their crops and project what price a future harvest will fetch. Even their apparently impotent petitions actually demonstrate their ability to negotiate and apply pressure on an empirewide stage, rather than any lack of agency (Hadjikyriacou 2014). Power, in other words, is not some abstract entity that a few possess and the rest must either suffer or resist. Power, space and empire are worked out in the specific relationships, negotiations, practices and materials of all participants, whether peasant or elite, human or nonhuman (Ertsen 2016, 6$7,11)$.

In this article my aim is to delineate both the global connections of the peasantry and the local embeddedness of the elite. In particular, I suggest an intricately networked landscape that replaces powerlessness, subsistence and isolation with interaction and community. The argument is based on the intensive survey and investigation of some 21 Ottoman settlements in the Northern Troodos Mountains of Cyprus as part of the Sydney Cyprus Survey Project (Given and Knapp 2003) and Troodos Archaeological and Environmental Survey Project (TAESP; Given et al. 2013b). Sources include not just archaeological survey and historical documents but architecture, historical photographs and oral history. These detailed demonstrations are taken in the broader context of the Ottoman period in Cyprus as a whole.

\section{Peasants and the land}

The interweaving of activities that constitutes peasant communities is closely associated with the land, a particular landscape which provides both arena and stimulus for interaction. It is not just human actors that interact, but the whole range of material and natural players (Given 2013; Plumwood 2009). This peasant landscape is not timeless or 'traditional', in spite of the strong historiographical tendency towards lumping together the Ottoman period in Cyprus (1571-1878) as a single phenomenon demonstrating the oppression or, alternatively, benevolence of Ottoman rule (Michael 2009, 22).

In Cyprus, the 17th to 19th centuries show several strong currents of development. Initially, timars or estates were handed out to cavalrymen in return for military service and supplying armed retainers; unusually, these timar-holders tended to stay in place and gradually evolved into local landowners, rooted in the land (Given and Hadjianastasis 2010, 45-46; Hadjianastasis 2009, 77-78). Feudal serfs were given the right to possess their land and bequeath it to their heirs, resulting in a widespread transition from feudal estates to communities of free smallholders (Inalcık 1973, 124, 133; Katsiaounis 1996, 29-31).

The activities and interactions of these smallholders make clear and consistent patterns across the villages of the Northern Troodos, and can be conceptualised as a series of concentric rings (see also Given 2004b, 175-180). The village of Mitsero in the central part of the Northern Troodos provides a characteristic example (Figure 2; Diacopoulos and Seretis 2003). At the core was the nucleated settlement, its organic, agglutinative layout structuring 
the dense and intricate associations of kinship, mutual support and internecine conflict (Ionas 1988, 17-31). In Figure 2 this core can be seen in the centre right (' $C$ '); the houses running up the hill to the left are a modern development. As well as the courtyard houses themselves, the villages were characterised by a range of social institutions, such as water fountains and spaces for meeting and exchanging information in a central square, increasingly formalised as coffee houses from the early eighteenth century (Faroqhi 2009a, 426-427). Churches and mosques drew together the inhabitants in a weekly and seasonal routine to share in ritual practices that were explicitly carried out as a community.

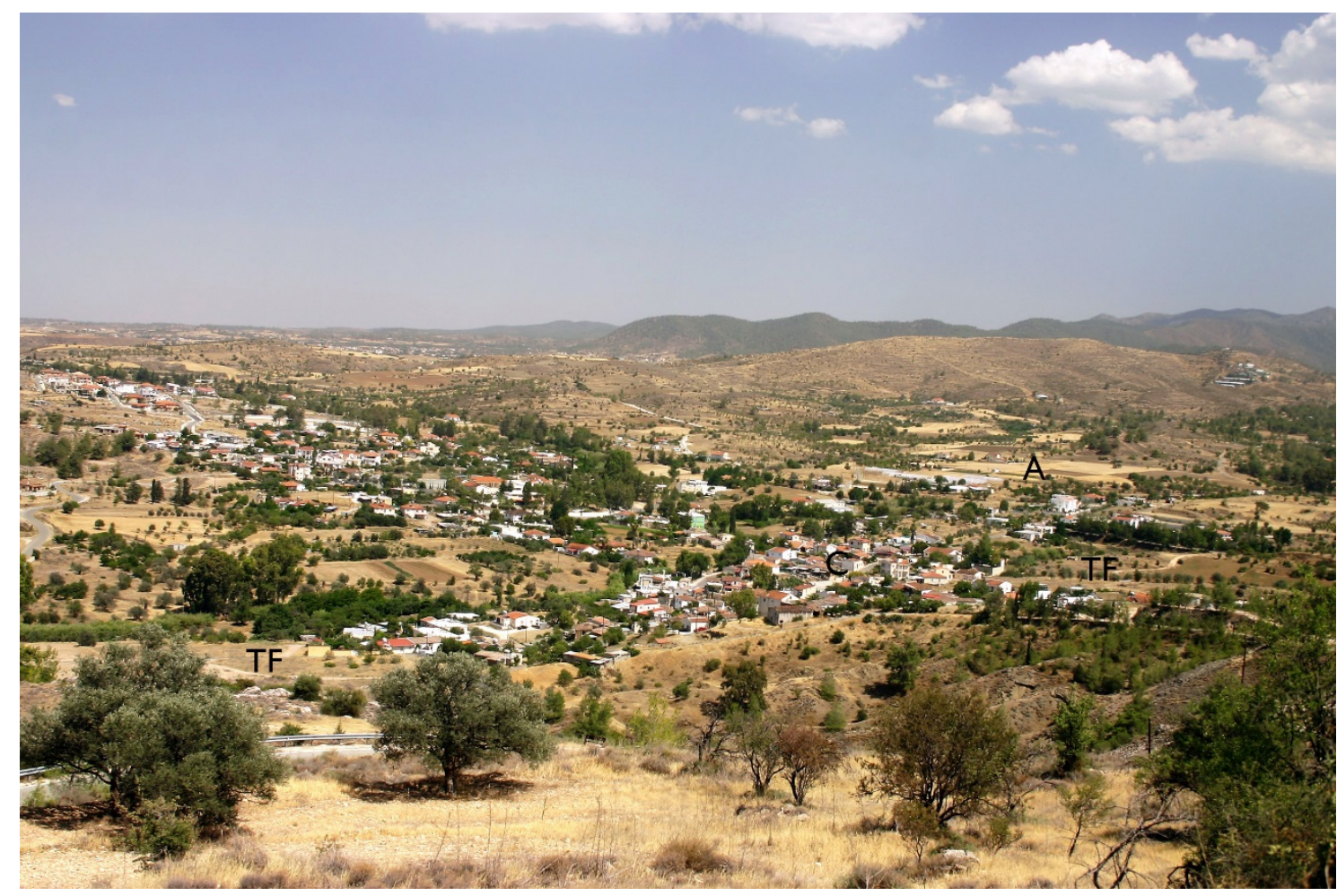

Figure 2. Mitsero village from the church of Panayia Lambadhiotissa, looking south-east. $A=$ arable land. $\mathrm{C}=$ historic core of the village. TF = cluster of threshing floors. (Michael Given)

The outskirts of the village constituted a separate zone, physically, conceptually and legally. The Mejelle, the code of Ottoman common law, sets aside this area, defined as where a person 'who has a loud voice' shouting from the edge of the village can be heard, for threshing, collecting firewood and common grazing (Mejelle 1901, 191). Spatially, this can be best seen in the clusters of family-owned threshing floors on a breezy spur or open area next to the village. In Mitsero they lie on the slope immediately north of the village and a spur to the west (marked TF in Figure 2). Oral histories of families helping each other and celebrating the end of the harvest set these communal activities firmly in this strictly delimited aural arena backed by the houses on the edge of the village and often overlooking the fields which provided income, sustenance and the ability to pay tax (Given 2004a, 126129; Whittaker 1999).

These fields are not just the locations of agricultural production and social relations, but are players themselves in the complex interactions among people, soils, crops, animals and water. This interaction takes a very material form: the boulders placed to mark a field boundary; the texture and fertility of the soil after the ox and ard have been through; the 
scatter of broken crockery that has come from the family's courtyard to their fields along with the manure, as mapped by archaeological survey projects (e.g. Boutin et al. 2013, 86; Given and Gregory 2003, 291). The radius of this zone of intensely cultivated fields from the village is typically 1-3 km (Given 2000, 215). In the case of Mitsero, a transect running due south from the centre of the village found relatively high densities of Ottoman (and generically Medieval-Modern) pottery within 500m of the village centre, and then a wider halo of sparser pottery extending to $1.5 \mathrm{~km}$ from the village. The arable land this transect passes through is marked ' $A$ ' in Figure 2.

As well as fields, property transfer documents show that villagers owned olive groves, shares in flour mills and oil presses, orchards and running water (Hadjianastasis 2004, 7075). A dense network of paths, often dendritic in form, connects all of this property, which is normally scattered throughout the village's territory, and makes it all part of the continual interaction. The cadastral plan for Mitsero, published in 1924 though with more recent additions, shows 13 tracks and paths radiating out from the village, with a significantly greater density of coverage in the southern portion leading to the arable land.

Beyond the fields are the outlands, a rich and constantly traversed source of grazing, forest resources, wild foods, and medicines (Forbes 1997). This was the land of the professional goatherds with up to about 100 goats, as opposed to the families grazing their handful of animals on the village outskirts. Their stone- and thorn-built goatfolds tended to ring the villages of their owners at a distance, carefully sited away from the arable land but still accessible (Given 2000, 221-223). In the case of Mitsero, the Sydney Cyprus Survey Project discovered three structures, one certainly and the other two probably goatfolds, on the hillslopes $2 \mathrm{~km}$ from the village to the north-west and south-west (Given et al. 2003, 109). Again, all of this was linked together by a network of paths. In the villages of the mountains and foothills, these typically rose from the villages and then contoured along below the ridgeline, cut into the hillside with a width of c. $0.8 \mathrm{~m}$ wide (Boutin et al. 2013, 144).

The peasant communities of Ottoman Cyprus were constituted by the intricate networks of local interactions across these diverse activity areas, an elaborate, sensory intertwining of people, soil, animals, paths, water, crops and wild plants (Given 2013). But does this mean that the peasants of Ottoman Cyprus lived their lives in isolation? What about the taxation, and the 'oppression and transgression' of landowners and tax farmers? This map of local intertwining needs to be set beside that other map showing the power and connections of the Ottoman Cypriot elite.

\section{Commercialisation and the control of production}

The scale of the elite's control of agricultural production in Cyprus, particularly by the late 18th century, is staggering. The tax-farming governor Haci Abdülbaki Ağa had by 1784 collected 16,000 kise, which comes to more than half the central Ottoman treasury's revenue for the year (Hadjikyriacou 2014). Investigations following the death of the Armenian merchant and consular dragoman Sarkis in c. 1810 showed that he had 30,000 kiles (770-924 metric tons) of grain in his warehouses, the equivalent of three-quarters of the total required from the whole island by the Ottoman military in 1800 (Hadjikyriacou 2014). The Greek Cypriot dragoman Kornesios Hadjiyorgakis shipped so much grain to Spain during the Napoleonic wars, in direct contravention of both Ottoman and British embargos, 
that, a foreign observer noted, he did not leave 'the lower orders a morsel of bread' (Kinneir, in Cobham 1908, 414; Hadjikyriacou 2015b).

How did this multi-ethnic elite acquire such power over agricultural production? The late 16th and 17th centuries saw the consolidation of a new elite, formed variously of the old Venetian nobility, Ottoman administrators, timar-holders and members of the military who became increasingly rooted in the island, higher prelates in the Orthodox church, other Greek Cypriots such as Hadjiyorgakis who could exploit the Ottoman system, and even foreign consuls and merchants. The Ottomans, then, became 'cypriotised', while the Cypriots and foreigners became 'ottomanised'. To increase both their wealth and their local power, this new elite became increasingly involved in agricultural production and commerce (Hadjianastasis 2009; Hadjikyriacou 2015a).

Accompanying this was a substantial growth in the commercialisation of agriculture and the production of cash crops. Partly this was a response to western Europe's increasing need for raw materials for their intensified production and manufacturing. It was also driven by the Ottoman state's need for provisions for the army and for Istanbul, and by this elite's own characteristic pursuit of commercial opportunity and profit (Hadjianastasis 2004, 77; Hadjikyriacou 2011, 37, 62-63). A good example is the growth in the production of cotton, which even in the Venetian period (1489-1571) had begun to overtake sugar as the principle cash crop, with large estates not just in the well-watered coastal plains of Paphos, Kouklia, Episkopi and Lapithos but also across the Mesaoria (Grivaud 1998, 374-375). Production increased significantly during the 17th century, feeding the textile workshops of, among others, Lancashire in England, where Cypriot cotton was considered of particularly high quality (Hadjianastasis 2009, 66).

This concentration of production was most directly served by large estates, whether owned by Islamic pious foundations, the Church, or owned privately as çiftliks by Ottoman, local or foreign notables. Most of these were formed in the late 17th and 18th centuries, through the reclamation of abandoned land or the dispossession of indebted peasants (Inalcık 1991). A developed infrastructure, particularly for irrigation, was an important element, and estates typically had a manager's residence, a range of storehouses, stables and cropprocessing facilities based on a courtyard, and housing for workers (Given and Hadjianastasis 2010, 47-50; Grivaud 1998, 395-397; Hadjianastasis 2004, 175-176).

This landscape of large-scale irrigation and cash cropping is not so distant from the world of the peasant farmer as might first appear. The Venetian sugar and cotton estates that came before can only be called plantations, with their labour-intensive irrigation systems and factories, and dependent on the exploitation of serfs, forced labour and significant numbers of slaves (Arbel 1993, 160-161; 1996, 188-189). Slavery still existed in the Ottoman period, but was almost entirely for domestic service; there is no actual evidence that slaves worked on çiftliks (Hatay 2009, 171). As we have seen, feudal serfs evolved into free landholders. Forced labour was technically reduced to one day a week, but there was minimal evidence that even this actually happened, and the last reference to forced labour is for 1613-14 (Hadjikyriacou 2011, 47-48). 
The production of cotton shows this shift in labour patterns most clearly. In 1805 the lonian consul, Panayis Angelatos, described three methods of growing cotton (Patapiou 2000, 196, 211-213). The best was 'cotton of running water', in other words fully irrigated. Then came 'cotton of gardens', watered from wells. The third, 'which predominates very much in terms of quantity compared to the other two', is sown in fields which are covered by winter floods and then left unirrigated. In other words, cotton grows best in Venetian-style irrigated plantations, but that was not what was used. During the Little Ice Age there were exactly the floods that Angelatos mentions, particularly in mountain valleys such as that of the Karkotis River, where substantial alluviation and boulder bars demonstrate their extent and power (Noller and Urwin 2013, 302). It was precisely this area, as noted Gaudry in 1855, that produced the best cotton in Cyprus $(1855,159-160)$.

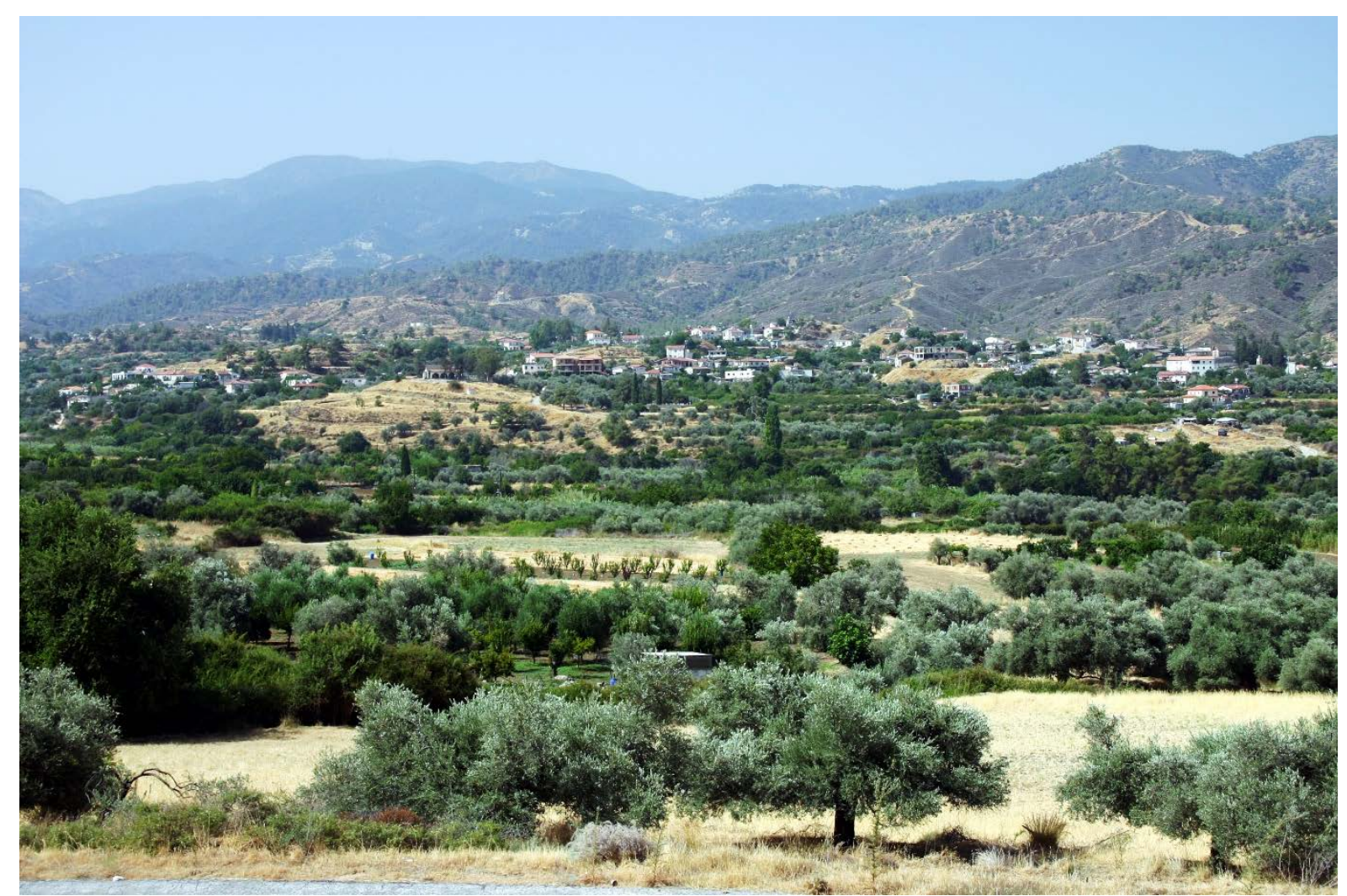

Figure 3. Karkotis Valley from the outskirts of Phlasou, looking north-west to Korakou (Michael Given)

This method of growing cotton does not depend on the imposition of a plantation-style landscape and workforce. It can operate more organically, with a smaller, non-coerced workforce. As Figure 3 shows, the landscape of the Karkotis Valley is very different from the sugar plantations of the Venetian period situated on the broad, level coastal plains and visually dominated by refineries and manor houses on spurs, or by the likes of Kolossi Castle. Here field divisions are highly involved, intricately bound up with the patterns of sediment deposition, a long history of interventions going back to the Roman period, and patterns of land ownership and daily routes linking fields with villages. In spite of the Karkotis being the highest and strongest river catchment in Cyprus, with excellent fertile soils and running water available in the summer, the land was predominantly cultivated by smallholders during the Ottoman period (Given et al. 2013a, 338). 
No work has yet been done on the mechanics of cotton cultivation and processing in Ottoman Cyprus, but a water mill on the Karkotis river below Kalliana, identified by local residents as a former cotton mill, is striking for having exactly the same form, scale and design as the grain mills of the same period (Ireland et al. 2013, 268). Like them, it was clearly a community-based facility, not a plantation factory.

This was very much in harmony with the wider shift from serfs to peasant farmers during the Ottoman period. Cotton became a cash crop cultivated by small-scale peasant farmers in family groupings, each engaged not just with the land but with market forces (Hadjikyriacou 2011, 43). Even within the çiftliks themselves, resident managers were often locals, and a substantial proportion of the labourers were in fact 'servants', in other words peasants who had declared themselves destitute, so becoming immune to taxation (Hadjikyriacou 2011, 143; Katsiaounis 1996, 34-35). This is a far cry from the plantations and forced labour of the Venetian period.

A similarly organic structure can be seen in what little survives of çiftlik architecture (see also Given and Hadjianastasis 2010, 47-48). This even applies to examples such as Potamia and Kouklia where they occupied the same buildings as their Lusignan and Venetian predecessors. Rather than maintaining and emulating the symmetry, coherence and monumentality of these manor houses, landowners, estate managers and residents appropriated them and added new courtyards and appendages which made the structures organic and agglutinative, using the same stone foundations and mud brick superstructure as peasant houses.

In the 19th century, for example, two additional courtyards of mud brick buildings were added on the west and south sides of the 14th century ashlar royal manor at Potamia (Lécuyer 2006, 249). The original symmetrical court of the manor house was appropriated and transformed, with new openings, two internal levels, dividing walls across the courtyard and habitations leaning against the manor's west wing (Lécuyer et al. 2004-2005, 1079). At the beginning of the 20th century a hamam was installed against one of the courtyard walls, and later oral tradition remembered a bakery and the homes of several families (Lécuyer $2006,249)$. The architecture suggests inclusivity and community participation more than monumentality and control.

For all the accumulated wealth of the likes of Abdülbaki, Sarkis and Hadjiyorgakis, the Ottoman Cypriot elite's control over production clearly worked very differently from the Medieval plantations and estates that preceded them. This particularly applied to the role of the labour force, now for the most part small-scale landholders rather than serfs. So what role did peasants play in this chain of production? How engaged were they in exchange, travel and communication across the island and beyond?

\section{Peasant connectivity and agency}

Seen from the perspective of the 'sea of land proprietors' (Katsiaounis 1996, 29) that comprised the rural landscape of Ottoman Cyprus, peasant life was neither circumscribed or isolated, nor, in spite of their entanglement in the profiteering of the elite, totally powerless. By examining some of the mechanisms of production, exchange and movement, 
it becomes clear that peasant farmers had considerable agency, connectivity and mobility, and that they participated in economic and social systems far more extensive than their own community territory.

As we have seen, peasants were fully engaged in all the negotiation and involvement with market forces entailed by the cash crop system. One particular mechanism for this, which seems to have been very widespread, was advance purchase, where the peasant would sell their crop to the merchant or moneylender before the harvest (Hadjikyriacou 2011, 209234). This would give them cash for paying taxes, and became particularly prevalent from the 18th century, when taxes increasingly needed to be paid in cash rather than kind. These were effectively loans payable on harvest of the crop, and carried considerable risks for the peasant, such as very substantial hidden interest rates. There were risks for the moneylender as well, as crops might be lost because of drought or locusts, or the peasant could renege on the debt and sell the crops for a better price elsewhere. What is clear is that the peasants were well aware of the fluctuation of prices, and these advance purchases had to be negotiated by the merchants, not imposed.

In one particular recorded case of advance payment in Prasteio (Morphou) in 1747-48, the agreement was that the cotton and wool sold in advance had to be delivered by the peasants to the port in Larnaca, $70 \mathrm{~km}$ to the south-east (Figure 4; Hadjikyriacou 2011, 224). This is just a single incident, but if, as seems likely, it was usual for the peasants to provide the delivery, this required regular and extensive travel, or else integration in a very substantial transport network. The well-known muleteers based at Athienou are an example of such a network, carrying out extensive transport between peasants, fairs, markets and warehouses across the centre and south-east of the island (Counts and Parvis 2011, 60-61).

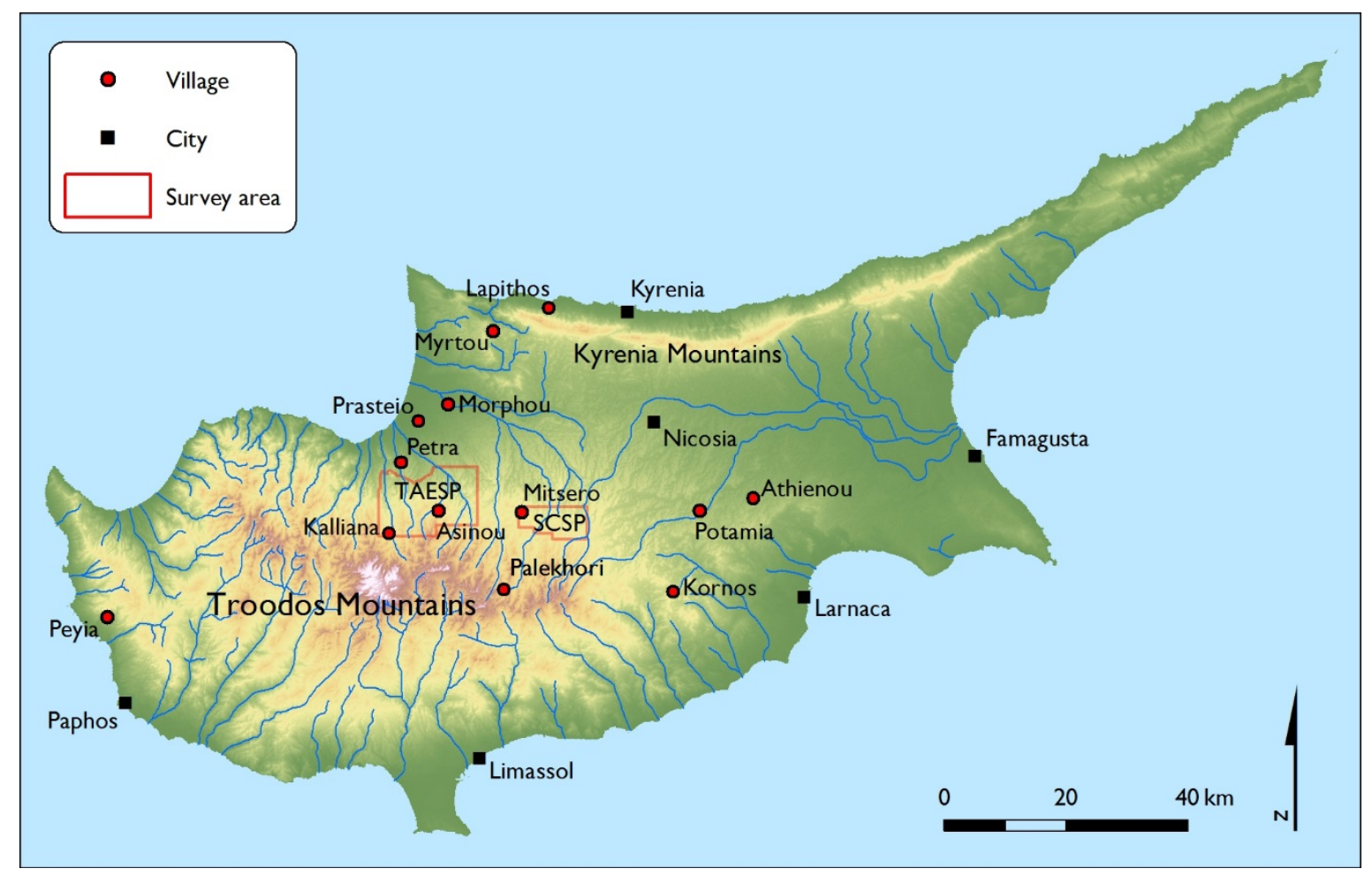

Figure 4. Map of Cyprus (Michael Given) 
The topographical diversity of Cyprus provides a wide range of environmental conditions for different crops, as well as buffering against localised effects of drought, locusts or hailstorms. To be effective as an economic system, this requires excellent communications and transport networks (Hadjianastasis 2004, 182-184; Hadjikyriacou 2014). Local markets were clearly crucial for the exchange of all manner of foodstuffs, agricultural equipment and household effects; being relatively close to a market made a substantial difference to the prosperity of a village (Hadjianastasis 2004, 179).

Travelling pedlars and craftworkers played a key role in the highly connected peasant economy. Pottery, for example, was mainly made by specialist villages close to good clay sources such as Kornos and Lapithos. Pitharia, the large clay storage jars, were so heavy that they had to be made in situ by itinerant specialists, but jugs and other vessels were also loaded onto donkeys and sold from village to village (lonas 1998, 147-149; London 1989). In time these were replaced by vehicles such as the village bus a mile outside the potteryproducing village of Kornos in the 1950s, shown in Figure 5.

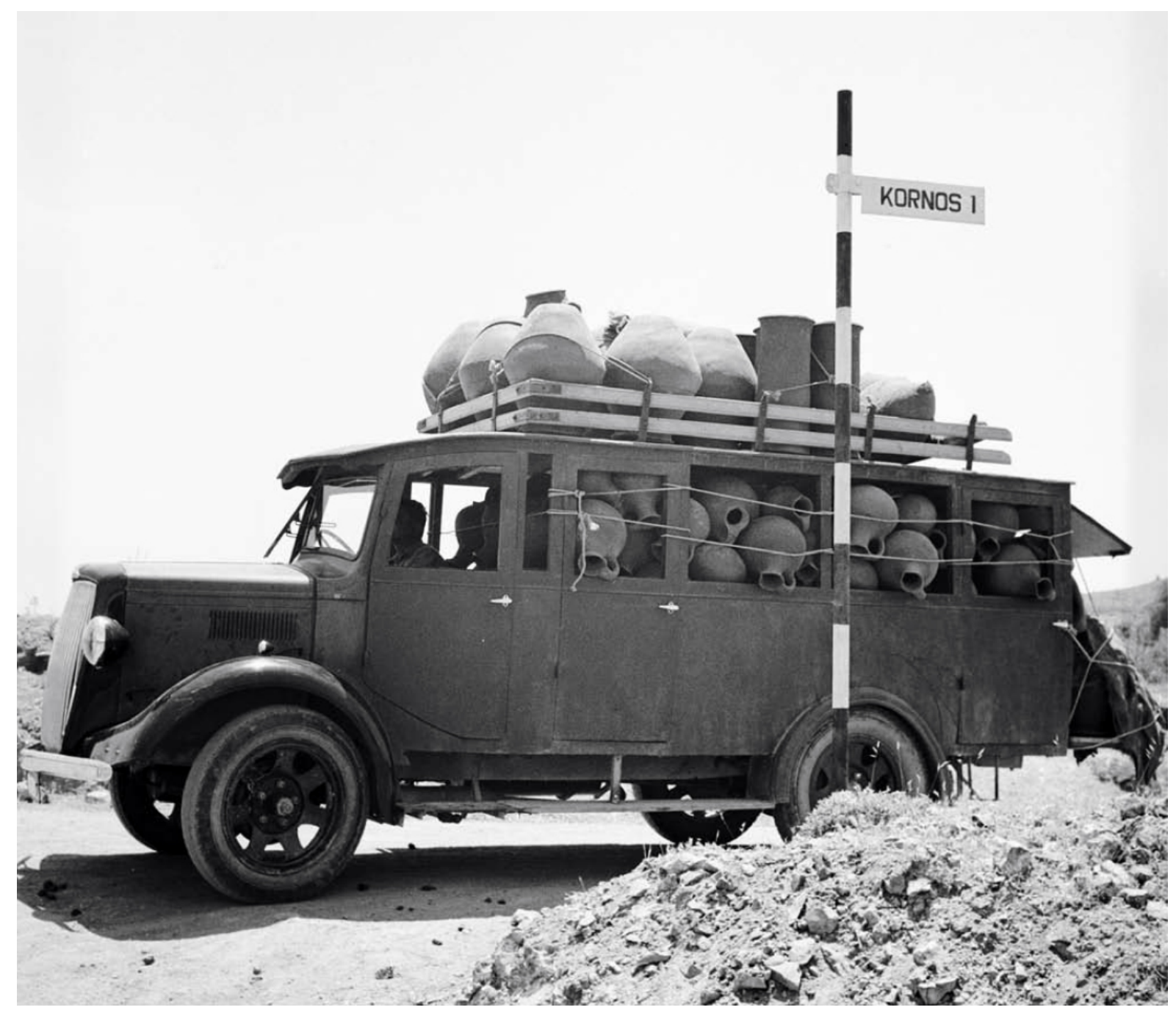

Figure 5. Bus loaded with pottery for selling across the island, 1950s (Archive of the Press and Information Office, Republic of Cyprus)

One specific commodity that shows a complex and island-wide system of purchase and maintenance, with strong regional variations, is the production of the chert flakes used in 
threshing sledges. McCartney's analysis of threshing sledge flakes found by the Troodos Archaeological and Environmental Survey Project shows that individual assemblages are made of between $66 \%$ and $100 \%$ of imported Lefkara cherts (McCartney 2013, 230-232). The lack of debris or unworked flakes in this material suggest that the sledges were brought in ready-made: as with the village of Alambra, these were clearly purchased in the major markets of Nicosia and Kyrenia.

With use, threshing sledges flakes become worn and break or are lost, so they need maintenance and patching. Occasional small quantities of debris from non-local chert, such as at the settlement of Mandres, suggest that itinerant knappers are bringing supplies of raw material. These knappes were common in the Paphos district, often following a seasonal round, quarrying the chert from sources in the south of the island and then passing through a series of villages, repairing sledges in preparation for threshing in early summer (Whittaker 1999, 14). Village fairs were also important in the Paphos district for bringing together knappers and customers (Stewart 2007, 334). In the TAESP Survey Area, judging by the knapping debris and the quality of the replacement flakes, it was more common for local, comparatively unskilled knappers to make them on an ad hoc basis out of low-quality local jasper and chalcedony.

A crucial element in this well-connected and highly mobile system of exchange consisted of the regular fairs on saints' days (Figure 1). At the fair of Saint Demetrios outside Nicosia in 1764 , as described by contemporary historian Kyprianos, 'the villagers buy and sell what they want for their fields, and for their winter use, they make terms with their creditors, and transact various business' (Cobham 1908, 357). He similarly notes the fair of Saint Panteleimon in Myrtou on July 27th, 1765, 'to which crowds flocked from all parts of Cyprus for worship and business' (Cobham 1908, 360; see also Turner in 1815: Cobham 1908, 432). These fairs were spread throughout the year in different places, elaborately intertwined with both agricultural and economic needs and the religious calendar (Hadjianastasis 2004, 184; lonas 2001). A photograph from the 1880s (Figure 6) shows the intense interaction and the inclusive nature of the negotiation, with women and children strongly represented. 


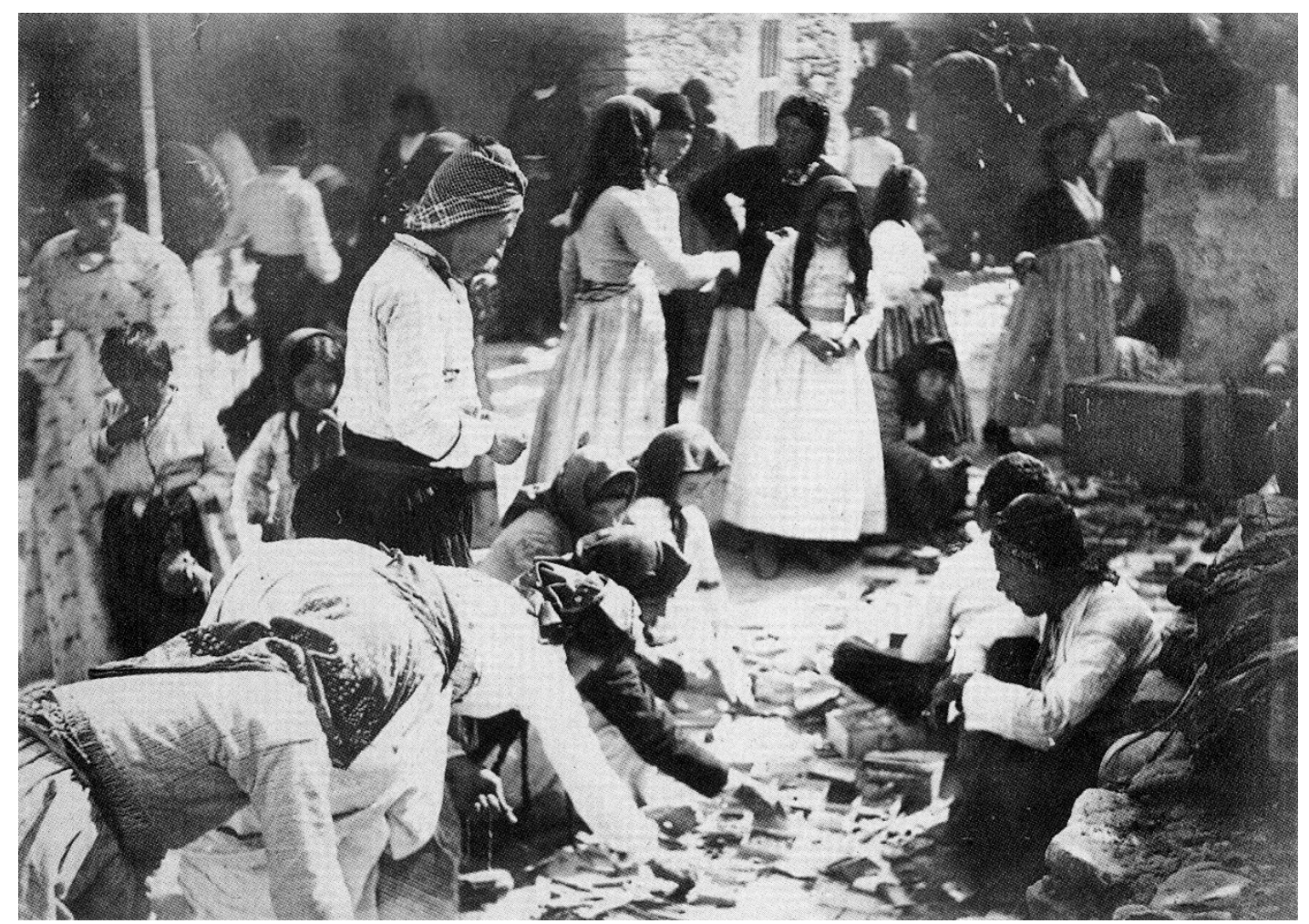

Figure 6. Buying and selling at the annual festival of Ayios Iraklidhios, Politiko, in the $1880 \mathrm{~s}$ (Ohnefalsch-Richter and Ohnefalsch-Richter 1994, 77a)

In northern Greece, where they tend to be better documented, fairs took place on 131 days in the year, and formed part of well-developed networks which systematically covered both the year and individual regions. Their importance not just for local exchange but for regional and even international trade is abundantly clear, and descriptions from the 17th to 19th centuries give vivid accounts of the extraordinary range of people, costumes, goods, coins and languages (Vryonis 1981, 217-226). In the Peloponnese, the economic importance of these large fairs increased in the 18th century as the opportunities provided by trade with the French commercialised production (220). This could only increase the knowledge, connections and influence of local producers at all scales. The experience of the peasant, both men and women, attending these fairs on a regular basis was anything but parochial and circumscribed.

At a more local level, the environmental and topographic diversity of areas such as the Northern Troodos of Cyprus meant that types of produce and facilities such as water power were not evenly distributed. People had to travel, connect and trade in order to acquire the full range of what they needed. This is very evident in the distribution of arable land and water mills in the survey area of the Troodos Archaeological and Environmental Survey Project (Figure 7). The middle section of the Karkotis River shown in the map has a copious water supply compared to all surrounding valleys and to its own valley further upstream and downstream. Villagers from beyond this section must travel up and down the valley or across watersheds from other valleys to grind their grain. This means that mills become nodes of interaction and information-sharing between people from different villages, particularly women (Given 2000, 226-227). 


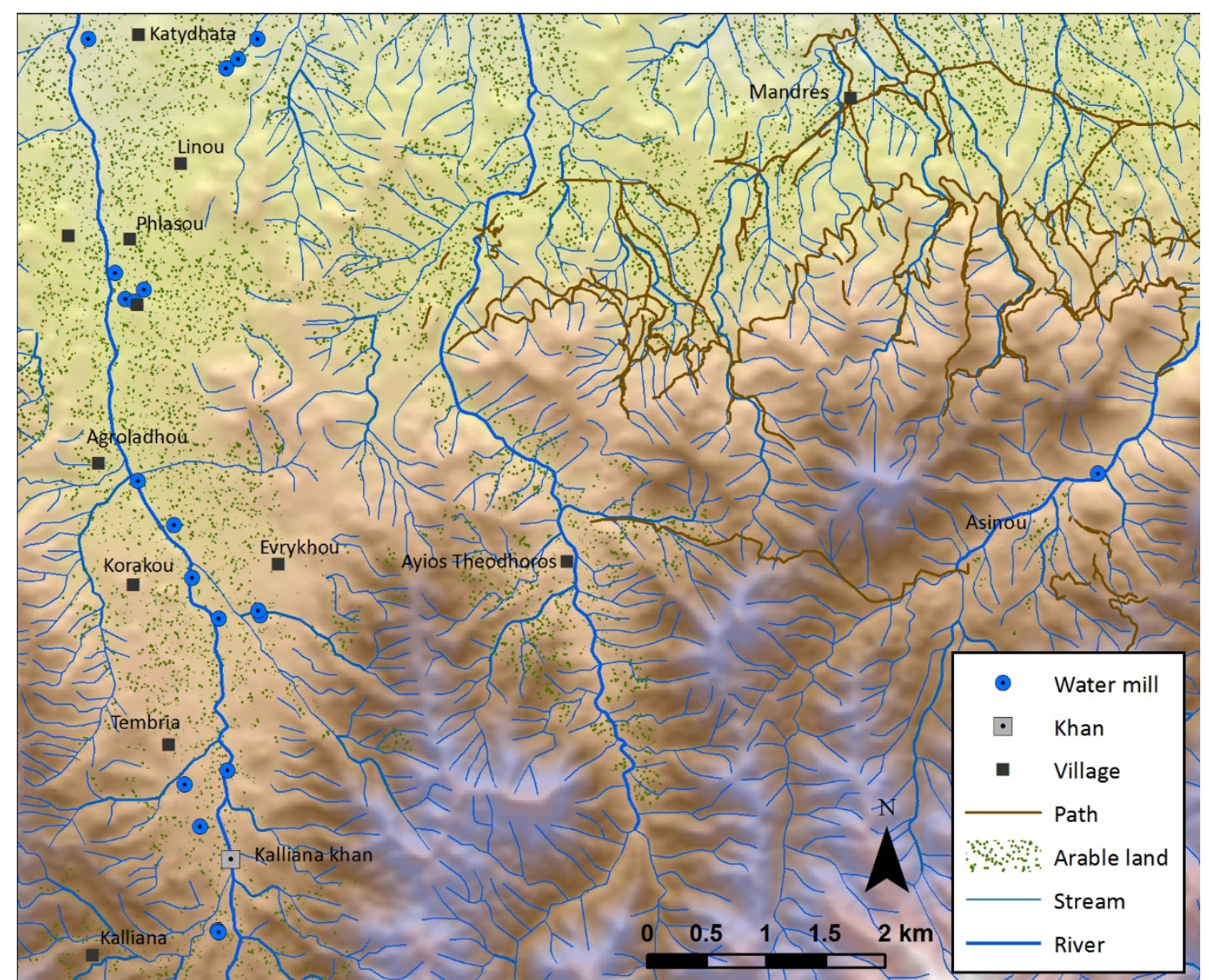

Figure 7. Map of Asinou \& Karkotis valleys, with paths, arable land, Medieval-Modern villages, khan and mills. The path survey by Erin Gibson was limited to the foothills south of Mandres, and the path between Asinou and Ayios Theodhoros. (Michael Given)

All of this movement of people and goods requires communication routes. Western travellers are clear that the road system was more appropriate to pedestrians and pack animals than vehicles (Turner in 1815: Cobham 1908, 428; e.g. Gaudry 1855, 139). This is supported by archaeological survey of well-preserved landscapes, particularly in the mountains. In the area north of Palekhori, for example, there is a complex network of carefully designed and maintained paths, on average c. $1.1 \mathrm{~m}$ wide, connecting Palekhori with a range of smaller villages (Gibson 2007, 66-74). Typically, they run along spur lines or contour the hillside, cut into the upper slope and built up over the lower slope, often with stone retaining walls up to $2 \mathrm{~m}$ high. Their complex junctions and intersections play an important role in directing the traveller. Similarly, in the survey area of the Troodos Archaeological and Environmental Survey Project, the mountain landscape is criss-crossed with paths between 0.7 and $1.2 \mathrm{~m}$ wide, contouring round hillsides, following river terraces and crossing watersheds (Figure 7). Similar systems of mountain paths have been recorded in the Makheras Forest (Burnet 2004, 100).

Oral historical accounts of the TAESP Survey Area are full of stories of the constant smallscale trade that took place on such paths (Gibson 2013, 289, 293-294). This particularly involved the transport of relatively small quantities of forest produce to the plains, particularly firewood and cheese. This created lines of regular travel and exchange that 
were perpendicular to the contours, such as between Asinou and the Morphou area (see Figure 4 for a map). One informant, who grew up in and around Asinou village, had particularly vivid memories of his father, who in the 1930s was a goatherd producing halloumi cheese and regularly travelled west to the Karkotis Valley (on the path shown in Figure 8 ) and north to the plains to sell mountain produce:

My father, in his spare time, and in order to provide better for us - because the halloumi in those days did not fetch such a good price, and there were many shepherds and the halloumi could not be sold in the villages around here - would take them to Galata, Kakopetria, Evrychou in Solia. ... He also dealt with timber. He cut dead wood from the pine trees, made them into the so-called gomarin, that is as much as he could load on a donkey, and took it to Petra, Zodhia, Morphou. ... And he bought some bread, some food and returned home in the evening. ... I remember some incidents, like the one I will mention, that we were waiting for my father, four brothers, to come from Petra, where he was taking the timber, from Asinou to Petra, it must be about ten kilometres. We would go on foot to a peak and watched for our father coming to give us bread to eat, because we were hungry. (TAESP Interview, 12 August 2003; see also Gibson et al. 2013, 224).

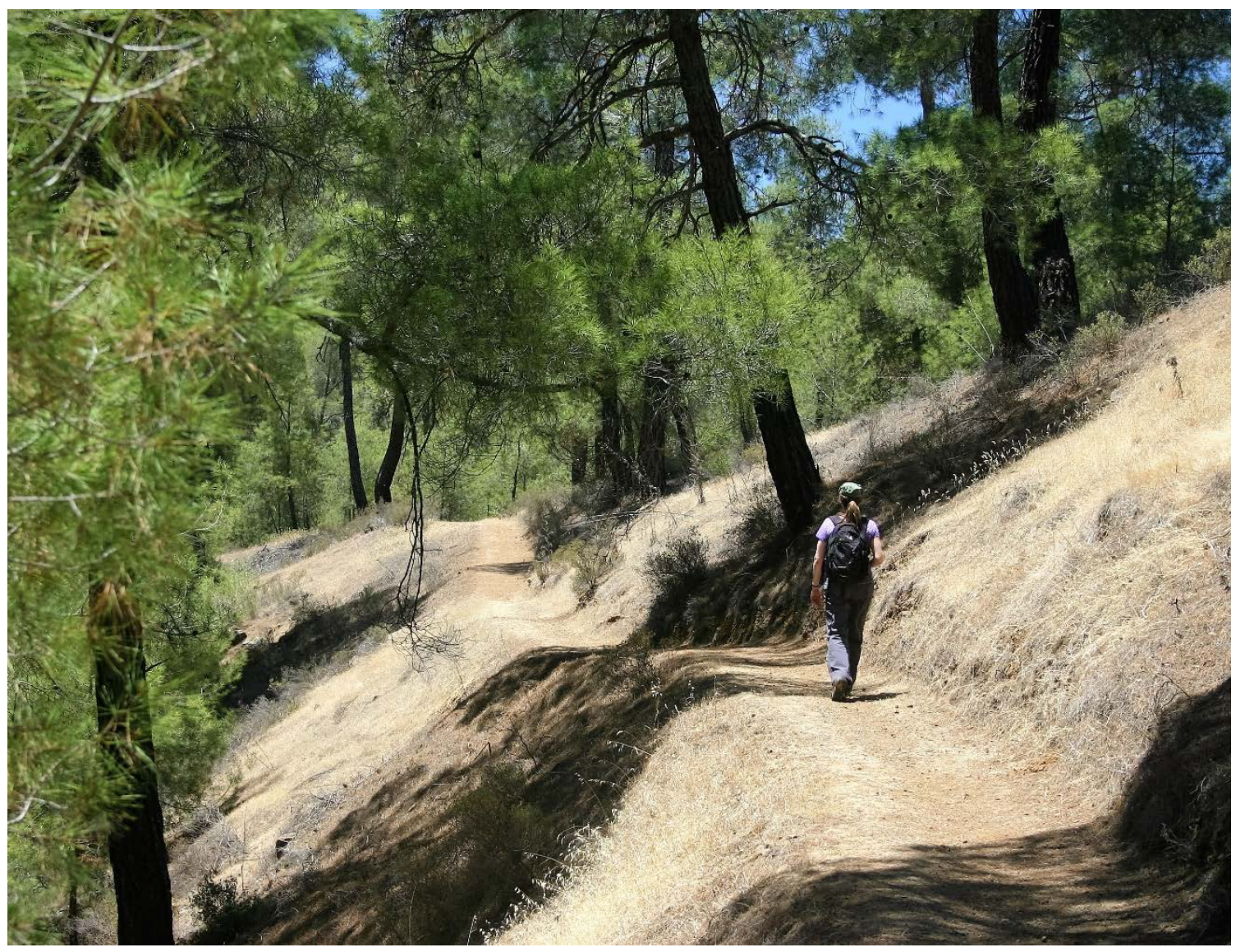

Figure 8. Mountain path between Asinou and Ayios Theodhoros, c. $1 \mathrm{~m}$ wide, restored by the Forestry Department as a nature and heritage trail. (Michael Given)

Another common pattern of movement was between mountain villages with little arable land and the plains settlements where they owned land specifically for growing cereals. Mandres is an example of one of these plains settlements, with unusual numbers of 
threshing floors for its size and no community institutions such as a church (Given et al. 2013c, 24-37). Several times during the spring and summer, farmers from the mountain villages of Galata, Kalliana and Tembria travelled down to Mandres to plough, reap, and thresh, and transported the grain back up. Informants remembered leaving Mandres at 3am to take the grain up to Galata, 9 km away, and returning the same day (Gibson 2013, 293). The dense network of paths recorded in Gibson's path survey north of Mandres show clearly how this regular movement was facilitated (Figure 7).

Longer distance routes were equipped with khans or caravanserais for accommodating travellers and their animals. The two-storey Kalliana khan, not in the village itself but on the main route going down the Karkotis Valley, had arcades to give shady but breezy accommodation and fireplaces for the winter, and ground floor rooms used for grocery shops and coffee shops (Figure 9; Ireland et al. 2013, 276). Local people remembered that farmers from mountain villages would stay there when bringing their grain to be ground in the water mills of the Karkotis River, or when travelling to Morphou in the plains to sell their produce (Gibson 2013, 289).

Nicosia, the capital, originally had 19 such khans, all or most from the Ottoman period, including the well-known Büyük Khan. Oral history from the 1940s and 1950s shows that they were used by all communities, and by people from villages and towns all over Cyprus. This made them important centres for the exchange of information, for example about market prices, and sites for a highly complex negotiation of social difference (Bakshi 2012, 116-118).

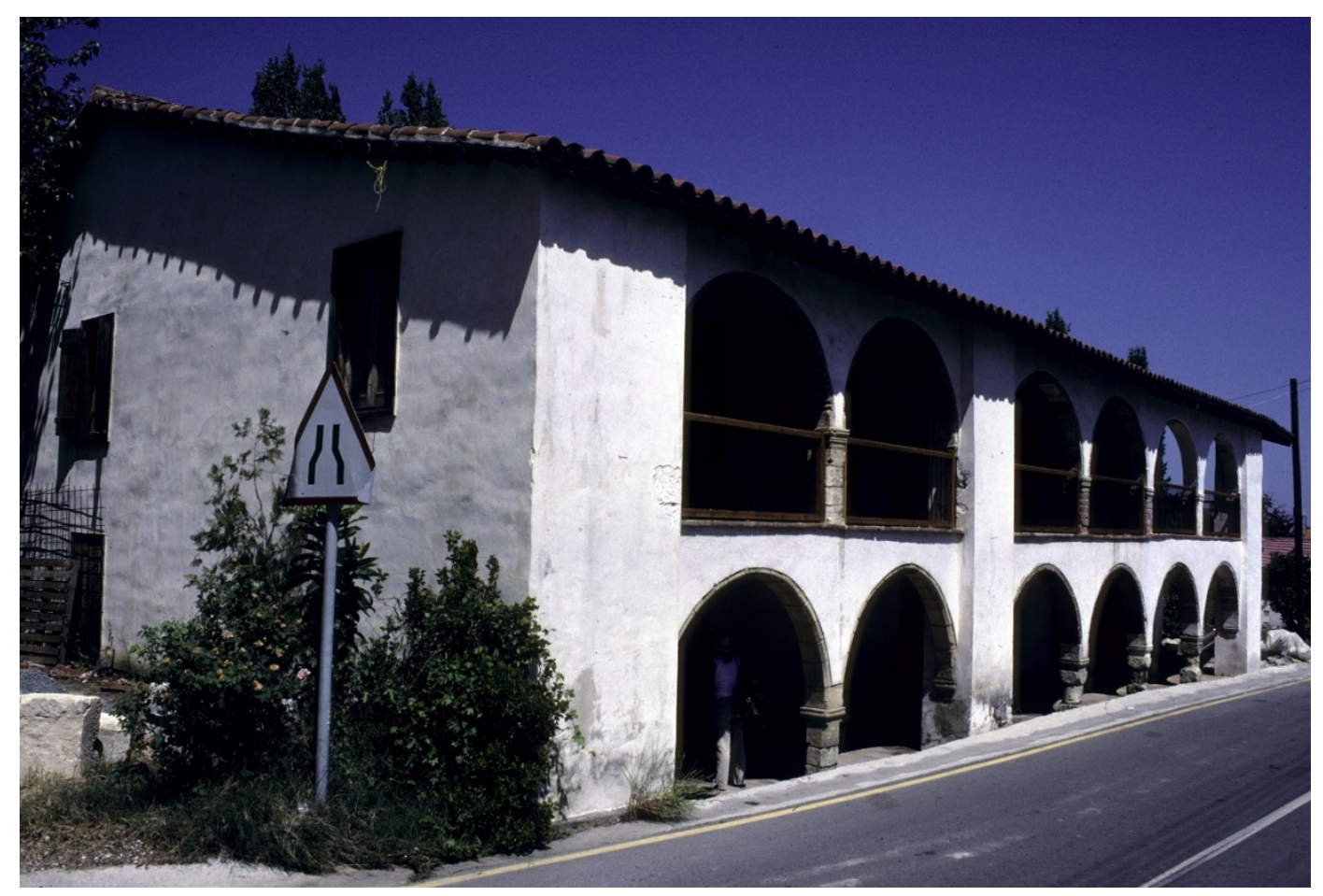

Figure 9. Kalliana khan (Chris Parks)

\section{Conclusion: global peasant, local elite}

Mobility was a key aspect of peasant life, in spite of ongoing stereotypes of subsistence and isolation (Adas 1986, 72-78; Smith 2014). In extreme cases of debt or oppression in Ottoman 
Cyprus, this included migrating to the Syrian or Turkish coast. This was an excellent means of avoiding the immediate problem, but also of pressuring the state into removing the oppressive administrator and offering tax breaks to lure the peasants - the state's main source of revenue - back to their land (Hadjikyriacou 2011, 124, 141-143). The archaeological and historical data show an active, engaged and highly connected peasantry, working the system when they could, resisting or protesting when they could not (Given 2004a, 116-137). This gave them the agency to constrain the elite and the authorities; by the intricate web of their material practices, interactions and connections, they participated in the construction and maintenance of the Ottoman Empire.

The elite, of course, had much greater scope in their interaction, which shows intricate and far-reaching administrative, professional, family and personal networks (Hadjianastasis 2011, 162). These networks and interactions made up the 'provincial loopings and meanderings of Ottomanness', a constant slippage of role and identity between localizing Ottomans and ottomanising locals (Aymes 2014, 179-180). The localizing tendencies are particularly significant: like the peasants, many were deeply rooted in particular places, whether they had emerged from an Ottoman, Venetian, Greek or European background. Being embedded in place and community, they contributed to the interconnected fabric of landscape and empire through their local networks of interaction, negotiation and competition.

The integration of historical, archaeological and ethnographic data suggests that interaction, communication and networking were key features of the social landscape at all levels, from landless workers and smallholders to merchants, governors and imperial officials. Every journey, conversation, load of merchandise, exchange and argument played its part in constituting place and constituting empire. The core of that empire was not Istanbul, but each and every landscape that orchestrated its own intricate network of connected peasants and localised elites.

\section{Acknowledgments}

I have learnt much from the participants, hosts and landscape of the Troodos Archaeological and Environmental Survey Project, Cyprus, particularly Marios Hadjianastasis, Panayiotis Alexandrou Loppas, Carole McCartney, and especially Erin Gibson for her insights into paths, mobility and interaction. I am very grateful to Erin Gibson, Marios Hadjianastasis, Antonis Hadjikyriacou and two anonymous reviewers for their very helpful comments on earlier drafts of this article. Thanks also to Ruth Keshishian for her help with Figure 5.

\section{About the author}

Michael Given is Senior Lecturer in Archaeology at the School of Humanities, University of Glasgow. His research interests include archaeological survey and landscape archaeology, the historical periods in the Eastern Mediterranean, and the relationship between people and the environment. Between 2002 and 2012 he was the co-director of the Troodos Archaeological and Environmental Survey Project in Cyprus. 


\section{References}

Adas, $\mathrm{M}$.

1986 From footdragging to flight: the evasive history of peasant avoidance protest in South and South-east Asia. Journal of Peasant Studies 13: 64-86.

http://dx.doi.org/10.1080/03066158608438292

Arbel, B.

1993 Slave trade and slave labor in Frankish and Venetian Cyprus. Studies in Medieval and Renaissance History 14: 151-190.

1996 The economy of Cyprus during the Venetian period (1473-1571). In The development of the Cypriot economy from the prehistoric period to the present day, edited by V. Karageorghis and D. Michaelides, pp. 185-192. Nicosia: University of Cyprus; Bank of Cyprus.

Aymes, $\mathrm{M}$.

2014 A provincial history of the Ottoman Empire: Cyprus and the Eastern Mediterranean in the nineteenth century. Translated by A. Morfee. SOAS/Routledge Studies on the Middle East. London: Routledge.

Bakshi, A.

2012 The legacy of Ottoman building in Nicosia: hans as spaces of coexistence in pre-conflict Cyprus. International Journal of Islamic Architecture 1: 107-128.

https://doi.org/10.1386/ijia.1.1.107 1

Baram, U. and L. Carroll

2000 The future of the Ottoman past. In A historical archaeology of the Ottoman Empire: breaking new ground, edited by U. Baram and L. Carroll, pp. 3-32. New York: Kluwer Academic/Plenum.

Boutin, A., M. Given, I. Banks, S. Digney, I. Evans, S. Floridou, R.S. Gabrieli, M. Hadjianastasis, M.T. Horowitz, T. Ireland, S. Janes, V. Kassianidou, A.B. Knapp, C. McCartney, J.S. Noller, M. Ntinou, C. Schriwer, S. Slevin, N. Urwin, J. Vroom and K. Winther-Jacobsen

2013 The Karkotis valley. In Landscape and interaction: the Troodos Archaeological and Environmental Survey Project, Cyprus. Volume 2: The TAESP landscape, edited by M. Given, A. B. Knapp, L. Sollars, J. S. Noller and V. Kassianidou, pp. 51-151. London: Council for British Research in the Levant.

Burnet, J.E.

2004 Forest bioresource utilisation in the Eastern Mediterranean since antiquity: a case study of the Makheras, Cyprus. BAR International Series 1243. Oxford: Archaeopress.

Chapman, O.M.

1937 Across Cyprus. London: John Lane.

Christodoulou, D.

1959 The evolution of the rural land use pattern in Cyprus. World Land Use Survey, Regional Monograph 2. Bude: Geographical Publications.

Cobham, C.D. (editor)

1908 Excerpta Cypria: materials for a history of Cyprus. Cambridge: Cambridge University Press. Counts, D.B. and J.A. Parvis

2011 Mapping Malloura: a carto-historical survey from the early modern period to the present. In Crossroads and boundaries: the archaeology of past and present in the Malloura Valley, Cyprus, edited by M. K. Toumazou, P. N. Kardulias and D. B. Counts, pp. 55-65. Boston: American Schools of Oriental Research.

Diacopoulos, L. and K. Seretis

2003 SIA 5: Mitsero village. In The Sydney Cyprus Survey Project: social approaches to regional archaeological survey, edited by M. Given and A. B. Knapp, pp. 109-118. Los Angeles: University of California at Los Angeles Cotsen Institute of Archaeology.

Ertsen, M.W. 
2016 'Friendship is a slow ripening fruit': an agency perspective on water, values and infrastructure. World Archaeology 49: 1-17. http://dx.doi.org/10.1080/00438243.2016.1246975

Faroqhi, S.

2009a The material culture of global connections: a report on current research. Turcica 41: 403431.

2009b Ottoman cotton textiles: the story of a success that did not last, 1500-1800. In The spinning world: a global history of cotton textiles, 1200-1850, edited by G. Riello and P. Parthasarathi, pp. 89-103. Oxford: Oxford University Press.

Forbes, $\mathrm{H}$.

1997 A 'waste' of resources: aspects of landscape exploitation in lowland Greek agriculture. In Aegean strategies: studies of culture and environment on the European fringe, edited by P. N. Kardulias and M. T. Shutes, pp. 187-213. Lanham: Rowman and Littlefield.

Gaudry, A.

1855 Recherches scientifiques en Orient entreprises par les ordres du Gouvernement, pendant les années 1853-1854. Partie agricole. Paris: Imprimerie Impériale.

Gibson, E.

2007 The archaeology of movement in a Mediterranean landscape. Journal of Mediterranean Archaeology 20: 61-87. http://dx.doi.org/10.1558//jmea.2007.v20i1.61

2013 Movement in the TAESP landscape. In Landscape and interaction: the Troodos Archaeological and Environmental Survey Project, Cyprus. Volume 1: methodology, analysis and interpretation, edited by M. Given, A. B. Knapp, J. S. Noller, L. Sollars and V. Kassianidou, pp. 286-295. London: Council for British Research in the Levant.

Gibson, E., I. Banks, S. Digney, I. Evans, S. Floridou, R.S. Gabrieli, M. Given, M. Hadjianastasis, T. Ireland, C. McCartney, J.S. Noller, C. Robins, C. Schriwer, L. Sollars, N. Urwin, J. Vroom and K. Winther-Jacobsen

2013 The mountains. In Landscape and interaction: the Troodos Archaeological and Environmental Survey Project, Cyprus. Volume 2: The TAESP landscape, edited by M. Given, A. B. Knapp, L. Sollars, J. S. Noller and V. Kassianidou, pp. 204-242. London: Council for British Research in the Levant.

Given, M.

2000 Agriculture, settlement and landscape in Ottoman Cyprus. Levant 32: 215-236. http://dx.doi.org/10.1179/lev.2000.32.1.209

2004a The archaeology of the colonized. London: Routledge.

2004b From density counts to ideational landscapes: intensive survey, phenomenology and the Sydney Cyprus Survey Project. In Mediterranean archaeological landscapes: current issues, edited by E. Athanasopoullou and L. Wandsnider, pp. 165-182. Philadelphia: University of Pennsylvania Museum of Archaeology and Anthropology.

2013 Commotion, collaboration, conviviality: Mediterranean survey and the interpretation of landscape. Journal of Mediterranean Archaeology 26: 3-26. http://dx.doi.org/10.1558/imea.v26i1.3

Given, M., J. Ellis Burnet, R. Schon, V. Kassianidou, S. Van Lokeren, L. Wells, N. Meyer, D. Coleman, T.E. Gregory, R.S. Moore and J.S. Smith

2003 SIA 4: Mitsero Mavrovounos. In The Sydney Cyprus Survey Project: social approaches to regional archaeological survey, edited by M. Given and A. B. Knapp, pp. 96-109. Monumenta Archaeologica vol. 21. Los Angeles: University of California at Los Angeles Cotsen Institute of Archaeology.

Given, M., R.S. Gabrieli, T. Ireland, J. Noller and J. Vroom

2013a Byzantine-Modern landscapes. In Landscape and interaction: the Troodos Archaeological and Environmental Survey Project, Cyprus. Volume 1: methodology, analysis and 
interpretation, edited by M. Given, A. B. Knapp, J. S. Noller, L. Sollars and V. Kassianidou. London: Council for British Research in the Levant.

Given, M. and T.E. Gregory

2003 Medieval to modern landscapes. In The Sydney Cyprus Survey Project: social approaches to regional archaeological survey, edited by M. Given and A. B. Knapp, pp. 284-294.

Monumenta Archaeologica vol. 21. Los Angeles: University of California at Los Angeles

Cotsen Institute of Archaeology.

Given, M. and M. Hadjianastasis

2010 Landholding and landscape in Ottoman Cyprus. Byzantine and Modern Greek Studies 34: 38-60. http://dx.doi.org/10.1179/030701310X12572436087055

Given, M. and A.B. Knapp

2003 The Sydney Cyprus Survey Project: social approaches to regional archaeological survey. Monumenta Archaeologica 21. Los Angeles: Cotsen Institute of Archaeology, University of California at Los Angeles.

Given, M., A.B. Knapp, J.S. Noller, L. Sollars and V. Kassianidou (editors)

2013b Landscape and interaction: the Troodos Archaeological and Environmental Survey Project, Cyprus. Volume 2: The TAESP landscape. 15. London: Council for British Research in the Levant.

Given, M., L. Sollars, A. Boutin, S. Digney, I. Evans, S. Floridou, R.S. Gabrieli, E. Gibson, M. Hadjianastasis, M.T. Horowitz, T. Ireland, S. Janes, A.B. Knapp, C. McCartney, J.S. Noller, C. Robins, C. Schriwer, S. Slevin, N. Urwin, J. Vroom and K. Winther-Jacobsen

2013c The plains. In Landscape and interaction: the Troodos Archaeological and Environmental Survey Project, Cyprus. Volume 2: The TAESP landscape, edited by M. Given, A. B. Knapp, L. Sollars, J. S. Noller and V. Kassianidou, pp. 6-50. London: Council for British Research in the Levant.

Grivaud, G.

1998 Villages désertés à Chypre (fin XIle - fin XIXe siècle). Meletai kai Ipomnimata 3. Nicosia: Archbishop Makarios III Foundation.

Hadjianastasis, M.

2004 Bishops, agas and dragomans: a social and economic history of Ottoman Cyprus 16401704. PhD, University of Birmingham.

2009 Cyprus in the Ottoman period: consolidation of the Cypro-Ottoman elite, 1650-1750. In Ottoman Cyprus: a collection of studies on history and culture, edited by M. N. Michael, M. Kappler and E. Gavriel, pp. 63-88. Near and Middle East Monographs. Wiesbaden: Harrassowitz.

2011 Crossing the line in the sand: regional officials, monopolisation of state power and 'rebellion'. The case of Mehmed Ağa Boyacıoğlu in Cyprus, 1685-1690. Turkish Historical Review 2: 155-176. http://dx.doi.org/10.1163/187754611X603092

2014 Between the Porte and the lion: identity, politics and opportunism in seventeenth century Cyprus. In Frontiers of the Ottoman imagination: studies in honour of Rhoads Murphey, edited by M. Hadjianastasis, pp. 139-167. Leiden: Brill.

Hadjikyriacou, A.

2011 Society and economy on an Ottoman island: Cyprus in the eighteenth century. PhD, School of Oriental and African Studies, London.

2014 Local intermediaries and insular space in late-18th century Ottoman Cyprus. Journal of Ottoman Studies 44: 427-456.

2015a The ottomanization of Cyprus: turbulent times of transition and the quest for new analytical tools. In Ottoman world: foundational coexistences, edited by D. Umit. Newcastle: Cambridge Scholars Publishing. 
2015b The province goes to the center: the case of Hadjiyorgakis Kornesios, dragoman of Cyprus. In Living in the Ottoman realm: sultans, subjects, and elites, edited by K. F. Schull and C. Isom-Verhaaren. Bloomington: Indiana University Press.

Hatay, M.

2009 Servants, slaves and concubines in Ottoman Cyprus (1571-1878). In Ottoman Cyprus: a collection of studies on history and culture, edited by M. N. Michael, M. Kappler and E. Gavriel, pp. 161-180. Near and Middle East Monographs. Wiesbaden: Harrassowitz.

İnalcık, $\mathrm{H}$.

1973 Ottoman policy and administration in Cyprus after the conquest. In Praktika tou Protou Dhiethnous Kiproloyikou Sinedhriou, edited by T. Papadopoulos and M. Christodoulou, pp. 119-136. Nicosia: Eteria Kipriakon Spoudhon.

1991 The emergence of big farms, çiftliks: state, landlords, and tenants. In Landholding and commercial agriculture in the Middle East, edited by Ç. Keyder and F. Tabak, pp. 17-34. Albany: State University of New York Press.

lonas, I.

1988 La maison rurale de Chypre (XVIIle-XXe siècle): aspects et techniques de construction. Nicosia: Cyprus Research Centre.

1994 Subsistence economy in Cyprus. Epetiris tou Kendrou Epistimonikon Erevnon 20: 433-453.

1998 Pottery in the Cyprus tradition. Publications of the Cyprus Research Centre 23. Nicosia: Cyprus Research Centre.

2001 Le calendrier du paysan chypriote. Epetiris tou Kendrou Epistimonikon Erevnon 27: 367398.

Ireland, T., I. Evans, E. Moutafov and C. Schriwer

2013 Architecture in the landscape. In Landscape and interaction: the Troodos Archaeological and Environmental Survey Project, Cyprus. Volume 1: methodology, analysis and interpretation, edited by M. Given, A. B. Knapp, J. S. Noller, L. Sollars and V. Kassianidou, pp. 261-277. London: Council for British Research in the Levant.

Jennings, R.C.

1986 The population, taxation, and wealth in the cities and villages of Cyprus, according to the detailed population survey (Defter-i Mufassal) of 1572. Journal of Turkish Studies, Raiyyet Rusumu Essays presented to Halil inalcık 10: 177-189.

Katsiaounis, R.

1996 Labour, society and politics in Cyprus during the second half of the nineteenth century. Texts and Studies in the History of Cyprus 24. Nicosia: Cyprus Research Centre.

Lécuyer, $\mathrm{N}$.

2006 Marquers identitaires médiévaux et modernes sur le territoire de Potamia-Agios Sozomenos. In Identités croisées en un milieu méditerranéen: le cas de Chypre (antiquitéMoyen Age), edited by S. Fourrier and G. Grivaud, pp. 241-256. Mont-Saint-Aignan: Universités de Rouen et du Havre.

Lécuyer, N., L. Vallauri and H. Breichner

2004-2005 Potamia-Agios Sozomenos. Bulletin de Correspondance Hellenique 128-129(1): 10781095. http://dx.doi.org/10.3406/bch.2004.7385

London, $\mathrm{G}$.

1989 On fig leaves, itinerant potters, and pottery production locations in Cyprus. In Cross-craft and cross-cultural interactions in ceramics. Ceramics and Civilization 4, edited by P. E. McGovern and M. D. Notis, pp. 65-80. Westerville, OH: American Chemical Society. McCartney, C.

2013 Lithics analysis. In Landscape and interaction: the Troodos Archaeological and Environmental Survey Project, Cyprus. Volume 1: methodology, analysis and interpretation, edited by M. Given, A. B. Knapp, J. S. Noller, L. Sollars and V. Kassianidou. Levant Supplementary Series. London: Council for British Research in the Levant. 
Mejelle

1901 The Mejelle. Translated by C. R. Tyser. Nicosia: Government Printing Office.

Michael, M.N.

2009 Introduction: the unchanging 'Turkish rule', the 'fair Ottoman administration' and the Ottoman period in the history of Cyprus. In Ottoman Cyprus: a collection of studies on history and culture, edited by M. N. Michael, M. Kappler and E. Gavriel, pp. 9-24. Near and Middle East Monographs. Wiesbaden: Harrassowitz.

Noller, J. and N. Urwin

2013 The environmental record of the TAESP landscape. In Landscape and interaction: the Troodos Archaeological and Environmental Survey Project, Cyprus. Volume 1: methodology, analysis and interpretation, edited by M. Given, A. B. Knapp, J. S. Noller, L. Sollars and V. Kassianidou, pp. 296-320. London: Council for British Research in the Levant.

Ohnefalsch-Richter, M. and M. Ohnefalsch-Richter

1994 Studies in Cyprus. Nicosia: Cultural Centre, Cyprus Popular Bank.

Patapiou, N.

2000 To proxeneio tis Eptanisou politeias stin Kyprou 1800-1807 kai o proxenos Panayis

Angelatos. Texts and Studies in the History of Cyprus 33. Nicosia: Cyprus Research Centre.

Plumwood, V.

2009 Nature in the active voice. Australian Humanities Review 46.

Rizopoulou-Egoumenidou, E.

1996 The economy of Cyprus under Ottoman rule with special emphasis on the late 18th and early 19th centuries. In The development of the Cypriot economy from the prehistoric period to the present day, edited by V. Karageorghis and D. Michaelides, pp. 193-207. Nicosia: University of Cyprus; Bank of Cyprus.

1998 Traditional forms of nutrition in Cyprus as known from written sources and oral tradition (18th-20th century). Rivista di Antropologia 76: 271-281.

Smith, M.E.

2014 Peasant mobility, local migration and premodern urbanization. World Archaeology: 1-18. http://dx.doi.org/10.1080/00438243.2014.931818

Stewart, S.

2007 Athkiakades ancient and modern: evidence of craftsmen and chert use from the Canadian Palaipaphos and Idalion Survey Projects in Cyprus. In Chert availability and prehistoric exploitation in the Near East, edited by C. Delage, pp. 327-344. BAR International Series. vol. 1615. Oxford: John and Erica Hedges.

Vryonis, S., Jr.

1981 The Panegyris of the Byzantine saint: a study in the nature of a medieval instution, its origins and fate. In The Byzantine saint: University of Birmingham fourteenth spring symposium of Byzantine studies, edited by S. Hackel. London: Fellowship of St Alban and St Sergius.

Whittaker, J.C.

1999 Alonia: ethnoarchaeology of Cypriot threshing floors. Journal of Mediterranean Archaeology 12: 7-25.

\section{Captions}

Figure 1. Villagers arriving at the fair of St George at Cape Drepano near Peyia in the 1930s (Chapman 1937, 145; see also 179-181)

Figure 2. Mitsero village from the church of Panayia Lambadhiotissa, looking south-east. $A=$ arable land. $\mathrm{C}=$ historic core of the village. TF = cluster of threshing floors. (Michael Given) 
Figure 3. Karkotis Valley from the outskirts of Phlasou, looking north-west to Korakou (Michael Given)

Figure 4. Map of Cyprus (Michael Given)

Figure 5. Bus loaded with pottery for selling across the island, 1950s (Archive of the Press and Information Office, Republic of Cyprus)

Figure 6. Buying and selling at the annual festival of Ayios Iraklidhios, Politiko, in the 1880s (Ohnefalsch-Richter and Ohnefalsch-Richter 1994, 77a)

Figure 7. Map of Asinou \& Karkotis valleys, with paths, arable land, Medieval-Modern villages, khan and mills. The path survey by Erin Gibson was limited to the foothills south of Mandres, and the path between Asinou and Ayios Theodhoros. (Michael Given)

Figure 8. Mountain path between Asinou and Ayios Theodhoros, c. $1 \mathrm{~m}$ wide, restored by the Forestry Department as a nature and heritage trail. (Michael Given)

Figure 9. Kalliana khan (Chris Parks) 